\title{
Analisis Butir Soal Ujian Matematika Kelas VII Semester Ganjil Tahun Pelajaran 2017/2018
}

\author{
Lia Hamimi $^{1 *}$, Riszki Zamharirah ${ }^{2}$, Rusydy $^{3}$ \\ 1,2,3 STKIP Muhammadiyah, Aceh Barat Daya \\ *)liahamimi@gmail.com
}

\begin{abstract}
Abstrak
Penelitian ini bertujuan untuk mengetahui tingkat kualitas soal yang teridiri dari validitas, tingkat kesukaran, relitabilitas, pengecoh, dan daya pembeda soal matematika di SMP N 1 Susoh semester ganjil kelas VII tahun akademik 2017-2018. Teknik penelitian ini menggunakan metode penelitian kuantitatif dengan populasi seluruh siswa SMP N 1 Susoh kelas VII tahun akademik 2017-2018. Sampel penelitian ini yaitu kelas VII B, diperoleh dengan menggunakan teknik random sampling (sampel acak). Pengumpulan data pada penelitian ini menggunakan metode dokumentasi dengan tujuan memperoleh informasi yang mendukung penelitian. Adapun dokumentasi yang dimaskud berupa soal dan lembar jawaban tes matematika tahun akademik 2017-2018. Hasil penelitian ini menunjukan bahwa soal yang digunakan relatif belum valid, karena masih terdapat beberapa soal yang memiliki validitas rendah dan sangat rendah. Solusinya, soal tersebut tidak digunakan dan dilakukan revisi. Selain itu, soal yang diteliti juga mempunyai tingkat reliabilitas yang rendah atau bisa dikatakan tidak reliabel. Namun, soal tersebut mempunyai tingkat kesukaran yang relatif baik, dengan hasil uji menunjukan mayoritas soal mempunyai tingkat kesukaran yang sedang. Hasil uji daya pembeda dan pengecoh menunjukan hasil yang baik untuk soal ujian bidang studi matematika kelas VII SMP 1 Negeri Susoh semester ganjil tahun akademik 2017-2018.
\end{abstract}

Kata kunci: analisis, soal ujian

\begin{abstract}
This study discusses the level of quality of questions consisting of validity, level of difficulty, relitability, deception, and distinguishing power of mathematical problems in SMP N 1 Susoh odd semester of class VII academic year 2017-2018. This research technique uses quantitative research methods with the participation of all students of SMP N 1 Susoh grade VII academic year 20172018. The sample of this study was class VII B, obtained using random sampling techniques. Data collection in this study uses a method created with the aim of obtaining information that supports research. Regarding the documentation included in the questions and answer sheets for the 20172018 academic year math test. The results showed that the questions used were relatively invalid, because there were still some questions that had low validity and were very low. The solution, this problem cannot be used and revised. In addition, the agreed questions also have a low level of reliability or can be accepted as unreliable. However, this problem has a relatively good level of suitability, with test results showing a moderate level of suitability. The results of the differentiation and deception test showed good results for the mathematics test questions for grade VII SMP 1 Susoh in the odd semester of the 2017-2018 academic year.
\end{abstract}

Keywords: analysis, exam questions

\section{Pendahuluan}

Perkembangan guru sebagai tokoh pendidikan utama mempunyai peranan penting atas maju mundurnya pendidikan. Berdasasrkan hal tersebut, guru dituntut untuk dapat melaksanakan serta mengolah pendidikan selaras dengan pendidikannya. Sebagai seorang 
guru yang baik, guru senantiasa harus memperhatikan siswanya untuk melihat perubahan yang terjadi selama dan setelah proses pembelajaran terjadi. Menurut Aunurrahman (2010:176): "Keberhasilan proses pembelajaran merupakan muara dari seluruh aktifitas yang dilakukan guru dan siswa." Artinya, apapun bentuk kegiatan-kegiatan guru, mulai dari merancang pembelajaran, memilih dan menentukan materi, pendekatan, strategi dan metode pembelajaran, memilih dan menentukan teknik evaluasi, semuanya diarahkan untuk mencapai keberhasilan belajar siswa.

Perubahan pada siswa diketahui dari evaluasi (penilaian) proses belajar mengajar. Hasil tes atau evaluasi merupakan alat ukur yang umum dipergunakan untuk menentukan pemahaman siswa terhadap materi yang sudah disampaikan. Selain itu, dari soal yang digunakan dapat dilihat apakah soal tersebut dapat mengukur tujuan kurikulum yang telah ditetapkan atau belum, sehingga hasilnya dapat dijadikan sebagai patokan keterlaksanaan tujuan pembelajaran.

Berdasarkan hal tersebut, seorang guru harus cermat untuk menentukan alat ukur yang akan digunakan untuk melihat tingkat keberhasilan proses pembelajaran yang dilaksanakan serta untuk mengukur tingkat pemahaman siswa. Hal ini sesuai yang dikemukakan oleh Bukhari (2005:12), yaitu: "Alat-alat yang digunakan oleh guru untuk mengumpulkan data mengenai siswa, dipilih betul-betul sebelumnya untuk mendapatkan keterangan mengenai kecerdasan seorang anak". Langkah pertama yang harus dilakukan oleh guru sebelum melakukan tes adalah dengan menguji kualitas soalnya terlebih dahulu. Arikunto (2010:207) menyatakan bahwa: "Untuk mengidentifikasi soal-soal yang baik, kurang baik dan soal yang jelek adalah dengan menganalisa soal tersebut. Terdapat beberapa hal yang berhubungan dengan analisa soal, yaitu taraf kesukaran, validitas, daya beda dan pola jawaban soal". Perlu diperhatikan dan dipenuhi faktor-faktor yang menentukan agar diperoleh suatu tes yang baik. Dengan demikian akan diperoleh hasil pengukuran yang tepat, benar dan dapat dipertanggungjawabkan dalam mengambil kesimpulan dan menetapkan keputusan yang dapat merugikan semua pihak yaitu sekolah dan siswa. Namun sering dilihat di lapangan adalah sebaliknya, banyak guru yang tidak memahami bagaimana seharusnya ia melaksanakan tes terhadap siswa. Tes yang dilaksanakan itu adakalanya tidak direncanakan sesuai dengan tujuan, sehingga kualitas tes tersebut masih diragukan baik validitas, tingkat kesukaran, serta daya pembedanya. Artinya, apakah suatu tes termasuk baik atau tidak, guru tidak mau tahu, yang penting bagi guru adalah tersedianya perangkat tes untuk melaksanakan penilaian (Arifin, 2010). 
Hasil observasi dan wawancara yang telah dilaksanakan pada guru matematika di SMP N 2 Susoh menunjukan bahwa pelaksanaan tes berjalan dengan lancar untuk semester ganjil tahun akademik 2017-2018. Soal tes langsung dibuat oleh guru matematika, dan terlebih dahulu memberikan kisi-kisi soal berdasarkan standar kompetensi dankompetensi dasar semester ganjil tahun akademik 2017-2018. Bentuk soal tes yang diberikan kepada siswa adalah berbentuk multiple choice (pilihan ganda) dan essay. Bentuk soal tersebut seragam dengan pelajaran lainnya yang diputuskan berdasarkan hasil musyawarah guru mata pelajaran di SMP Negeri 1 Susoh. Pelaksanaannya sesuai dengan jadwal yang telah ditentukan dalam kalender pendidikan.Tessumatif diadakan pada akhir satu unit program pelajaran atau akhir semester yang gunanya untuk penentuan nilai siswa setelah mengikuti pelajaran dalam satu semester.

Dari hasil ujian yang telah dilaksanakan, diperoleh hasil yang kurang memuaskan karena nilai rendah yang didapat oleh siswa. Menurut guru Matematika di sekolah tersebut hasil ujian mata pelajaran Matematika kelas VII semester ganjil tahun pelajaran 2017/2018 kurang memuaskan (Sumber: Guru Matematika kelas VII). Secara tidak langsung dapat dikatakan bahwa sebagian siswa tidak mampu menjawab soal yang diberikan oleh guru. Oleh karena itu, perlu analisis yang mendalam mengenai kriteria soal yang dibuat guru tersebut.

Beberapa penelitian serupa pernah dilaksanakan, salah satunya penelitian yang dilakukan oleh Karman (2012) diperoleh kesimpulan bahwa: "Soal ujian bidang studi Matematika semester ganjil kelas VII SMP Negeri 2 Susoh tahun pelajaran 2011/2012 belum memiliki validitas dan tingkat kesukaran yang baik karena setelah dianalisis validitas item soal masih tergolong rendah”. Selain itu, penelitian lain juga dilakukan oleh Mursyidah (2017) menunjukan bahwa kualitas soal sudah dinyatakan baik berdasarkan tingkat validitas, reliabilitas, daya pembeda, tingkat kesukaran, dan pengecoh.

Adapun rumusan masalah pada penelitian ini adalah untuk mengetahui kualitas soal matematika di SMP N 1 Susoh, kelas VII tahun akademik 2017-2018.

\section{Metode Penelitian}

Teknik penelitian ini menggunakan jenis penelitian deksriptif kuantitatif untuk mengetahui kualitas soal matematika semester ganjil tahun akademik 2017-2018 di kelas VII SMP N 1 Susoh. Keuntungan penelitian deskriptif yaitu dapat melakukan penelitian yang lebih mendalam dan mendapat kesempatan untuk memperoleh wawasan mengenai 
konsep-konsep dasar tingkah laku manusia. Tujuannya untuk mengetahui bagaimana kriteria soal matematika semester ganjil tahun 2017/2018 dikelas VII di SMP Negeri 1 Susoh.

Subjek penelitian merupakan salah satu hal yang perlu diperhatikan, karena penelitian itu sendiri mengambil kesimpulan tentang subjek secara keseluruhan yaitu populasi dan sampel. Untuk mengumpulkan data penelitian, penulis menggunakan instrumen penelitian agar dapat di analisis yaitu dengan menggunakan dokumentasi. Adapun teknik penelitian ini adalah

a. Analisis Validitas Item Soal

Untuk menentukan validitas item dengan menggunakan teknik korelasi product moment dimana angka korelasinya diberi lambang dengan $\mathrm{r}_{\mathrm{xy}}$ yang dapat diperoleh dengan menggunakan rumus :

$$
r_{x y}=\frac{N \sum x y-\sum x \sum y}{\sqrt{\left[N\left(\sum x^{2}\right)-\left(\sum x\right)^{2}\right]\left[N\left(\sum y^{2}\right)-\left(\sum y\right)^{2}\right]}}
$$

Dengan: $r_{x y}$ : koefisien validitas

$\mathrm{x} \quad$ : skor/ jawaban betul dari tiap butir soal tes

y : skor total

$\mathrm{N} \quad$ : jumlah peserta tes

Kriteria untuk menentukan koefisien validitas butir soal menurut Masidjo (2007:243) sebagai berikut:

$$
\begin{array}{ll}
0,91-1,00 & : \text { sangat tinggi } \\
0,71-0,90 & : \text { tinggi } \\
0,41-0,70 & : \text { cukup } \\
0,21-0,40 & : \text { rendah } \\
\text { negatif-0, } 20: \text { sangat rendah }
\end{array}
$$

b. Analisis Reliabilitas

Analisis reliabilitas pada penelitian ini menggunakan teknik belah dua dengan korelasi produk momen dengan indeks reliabilitas sebagai berikut (Arikunto, 2010):

$$
r_{11}=\frac{2 r_{1 / 2} \frac{1}{2}}{1+r_{1 / 2} 1 / 2}
$$

c. Analisis Tingkat Kesukaran

Tingkat kesukaran soal ditentukan menggunakan indeks kesukaran dengan nilai 
antara 0.00 sampai dengan 1.00. Menurut Arikunto tingkat kesukaran menurut Arikunto (2010:208) dapat dihitung dengan rumus sebagai berikut :

$$
\mathrm{p}=\frac{\mathrm{B}}{\mathrm{Js}}
$$

Dengan :

$$
\begin{array}{ll}
\mathrm{P} & \text { : Tingkat kesukaran } \\
\mathrm{B} & \text { : Jumlah siswa menjawab benar } \\
\text { Js } & \text { : Total seluruh siswa }
\end{array}
$$

Kriteria indeks kesukaran soal menurut Sudjana sebagai berikut :

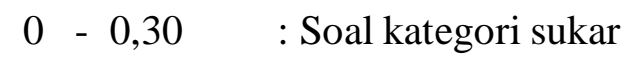

0,31-0,70 : Soal kategori sedang

$0,71-1,00 \quad$ : Soal kategori mudah.

Formula tersebut dipergunakan untuk menentukan nilai tingkat kesukaran soal berbentuk pilihan ganda. Adapun untuk soal yang berbentuk uraian, penentuan nilai tingkat kesuakran dilakukan menggunakan ketentuan bedasarkan Antony (2012) berikut:

$$
\text { mean }=\frac{\text { jumlah skor siswa peserta tes pada butir soal tertentu }}{\text { banyaknya siswa peserta tes }}
$$

Kemudian dilanjutkan dengan proses berikut:

$$
\text { Tingkat Kesukaran }=\frac{\text { Mean }}{\text { Skor Maksimum yang ditetapkan }}
$$

Adapun klasifikasi tingkat kesukaran soal ditentukan berdasarkan kategori berikut:

$$
\begin{array}{ll}
0,00-0,30 & \text { sukar } \\
0,31-0,70 & \text { sedang } \\
0,71-1,00 & \text { mudah. }
\end{array}
$$

d. Analisis Daya Pembeda

Daya pembeda ditentukan menggunakan formula berikut:

$$
D P=\frac{B_{A}}{J_{A}}-\frac{B_{B}}{J_{B}}
$$

Keterangan:

$\mathrm{DP}=$ Daya pembeda

$\mathrm{BA}=$ Banyaknya perserta tes kelompok atas yang menjawab benar

$\mathrm{BB}=$ Banyaknya peserta tes kelompok bawah yang menjawab benar 
$\mathrm{JA}=$ Jumlah peserta tes kelompok atas

$\mathrm{JB}=$ Jumlah peserta tes kelompok bawah.

Arikunto (2010).

Berikut klasifikasi nilai daya pembeda suatu soal:

$$
\begin{array}{ll}
0,00 \leq \mathrm{DP} \leq 0,19 & \text { Jelek } \\
0,20 \leq \mathrm{DP} \leq 0,39 & \text { Cukup } \\
0,40 \leq \mathrm{DP} \leq 0,69 & \text { Baik } \\
0,70 \leq \mathrm{DP} \leq 1,00 & \text { Baik sekali } \\
\text { Negatif } & \text { Tidak baik, }
\end{array}
$$

e. Analisis Pengecoh

Analisis pengecoh dilakukand engan tujuan untuk mengetahui seberapa besar pengecoh terebut befungsi pada soal yang telah dibuat, adapun penentuannya dilakukan berdasarkan nilai persentase, apabila paling sedikit peserta tes dipilih oleh 5\% pengikut tes.

\section{Hasil dan Pembahasan}

\section{Hasil}

Pada bagian ini akan dipaparkan data-data yang berkenaan dengan kegiatan penelitian dan subyek penelitian selama melaksanakan penelitian. Data dalam kegiatan penelitian ini yaitu data dari soal dan jawaban siswa dari tes muliple choice (pilihan ganda) pelajaran matematika yang diberikan guru pada ujian semester ganjil tahun 2017/2018. Kedua dokumen tersebut dijadikan pertimbangan untuk menentukan kualitas soal matematika kelas VII di SMP N 1 Susoh semester ganjil tahun akademik 2017-2018.

Data diperoleh dari hasil tes yang telah dilaksanakan. Data tersebut kemudian diolah dan dianalisis menggunakan teknik analisis data berdasarkan pada yang telah dijelaskan pada bagian metode. Berdasarkan hasil jawaban siswa, soal nomor 9, 16, 18, dan 19 tidak dapat dianalisis karena terdapat kesalahan redaksi di dalam soal tersebut sehingga tidak dapat dikerjakan oleh siswa.

\section{Pembahasan}

a. Validitas Butir Soal

Hasil penelitian menunjukkan bahwa tingkat validitas item soal ujian semester ganjil kelas VII SMP Negeri 1 Susoh bidang studi Matematika tahun pelajaran 2017/2018 sebagian besar tergolong sangat rendah dan rendah.Hal tersebut berdasarkan pada hasil 
analisa 20 buti soal pilihan ganda, dimana hasilnya menunjukan bahwa hanya terdapat 4 soal yang dinyatakan valid, dan sisanya sebanyak 16 soal dinyaktan tidak valid.

Jadi, dapat dikatakan bahwa keseluruhan butir soal multiplechoice belum mendukung validitas item. Dengan demikian soal bentuk multiple choiceyang digunakanbelum valid karena tingkat validitas itemnya sebahagian besar masih tergolong rendah bahkan ada yang sangat rendah. Soal-soal yang memiliki validitas item yang rendah dan sangat rendah jangan digunakan lagi dan harus direvisi atau diperbaiki kembali.

\section{b. Reliabilitas Butir Soal}

Reliabilitas soal multiple choice diperoleh dari hasil analisis korelasi product moment dari soal dengan metode belah dua awal dan akhir. Selanjutkan indeks reliabilitas dihitung dengan menggunaan rumus Spearman-Brown.Dari hasil analisis data diperoleh bahwa $r_{11}=0,17$ sehingga indeks reliabilitas kurang dari pada 0,70 , artinya bahwa hasil tersebut mempunyai tingkat reliabilitas yang rendah atau tidak reliabel. Menurut Aiken (Suryana Surapranata, 2009) bahwa koefisien reliabilitas mempunyai peranan besar pad tingkat kesukaran soal, dengan ketentuan semakin rendah nilai reliabilitas soal, semakin sukar soal tersebut dan berlaku sebaliknya.

\section{c. Tingkat Kesukaran Butir Soal}

Penentuuan tingkat kesukaran soal dilakukan dengan cara menghitung persentase siswa yang menjawab soal dengan benar. Apabila semakin sedikit siswa yang mejawab benar kelompok soal tersebut, artinya soal tersebut dapat dikatakan sukar dan berlaku sebaliknya. Adapun pada soal yang diteliti pada kategori pilihan ganda, 5 butir soal termasuk kategori sukar dengan nomor soal 2,3,4,13, dan 20, sedangkan sisanya dikategoikan sebagai soal yang mudah dan sedang.

Lima soal atau sebesar $32 \%$ menunjukan soal yang diteliti memiliki tingakt kesukaran sukar. Berdasarkan Arikunto (2013), soal yang baik mempunyai kriteria tingkat kesukaran yang tidak terlalu mudah dan tidak terlalu sukar. Alasannya karena soal yang terlalu mudah tidak dapat digunakan sebagai alat ukur kemampuan siswa, karena tidak akan merangsang siswa befikir untuk memecahkan masalah pada soal tersebut. Sebaliknya, soal yang terlalu sukar dapat menyebabkan siswa putus asa dan cenderung juga tidak bisa digunakan sebagai alat ukur dikarenakan dapat diasumsikan bahwa kemampuan siswa berada di bawah tingkat kesukaran soal tersebut. 
Selanjutnya sebesar $62.5 \%$ soal mempunyai tingak kesukaran sedang. Hal tersebut dapat diterima atau dinyatakan valid, berdasarkan pernyataan arikunto sebelumnya. Selanjutnya, satu soal $(6.25 \%)$ mempunyai tingkat kesukaran mudah. Kesimpulannya soal tersebut tidak baik, karena terlalu mudah, berdasarkan penjelasan sebelumnya.

d. Daya Pembeda Butir Soal

Berdasarkan data yang telah terkumpul dan setelah proses analisis data diperoleh daya pembeda dari 16 butir soal multiple choice. Terdapat dua soal yang memiliki daya pembeda yang baik, yaitu soal nomor 5 dan 6 . Selanjutnya, 6 soal mempunyai daya pembeda yang cukup, yaitu nomor 3, 4, 10, 12, 14, dan 15. Sedangkan 6 soal sisanya mempunyai daya pembeda yang jelek serta dua soal, yaitu butir 11 dan 17 mempunyai daya pembeda yang tidak baik.

Simpulannya dari 16 butir soal pilihan ganda tersebut, sebanyak $12.5 \%, 2$ butir soal, mempunyai datay pembeda yang tidak baik. Dengan kata lain soal tersebut tidak dapat digunakan ataupun di revisi, melainkan dengan menggantinya dengan soal yang baru. Berdasarkan Firmansyah (2018), butir soal dengan tingkat daya pemebeda rendah masih dapat diperbaiki. Untuk soal yang mempunyai tingkat daya pembeda yang rendah, disarankan untuk diganti namun masih tetapi direvisi. Sedangkan, untuk kasus daya pembeda yang jelek, soal tersebut tidak dapat diperbaiki maupun digunakan, solusinya hanya dengan mengganti dengan soal yang baru. Artinya bahwa soal tersebut memang benar-benar tidak layak untuk digunakan.

\section{e. Pengecoh (distractor) Butir Soal}

Untuk menganalisis berfungsinya pengecoh yang dibuat guru pada soal ujian semester ganjil bentuk multiple choice kelasVII SMP negeri 1 Susoh tahun pelajaran 2017/2018 bidang studi matematika, penulis melihat pola dari jawaban siswa dari pilihan jawaban yang tersedia dengan pola A, B, C, dan D. Dari hasil analisis pengecoh, hampir semua pengecoh yang dibuat guru berfungsi dengan baik karena dipilih lebih dari 5\% siswa yang mengikuti ujian.Hal tersebut mengacu pada pendapat Arikunto (2009) yang menyebutkan bahwa suatu pengecoh dapat berfungsi dengan baik apabila minmum dipilih oleh 5\% dari kesluruhan peserta tes. Lebih jauh menurut Firmansyah (2018), suaut pengecoh tidak befungsi dengan baik apabila hasil pada setiap opsi butir soal menyatakan salah satu dari kurang baik, jelek, atau sangat jelek. Akibatnya fungsi dari pengecoh tersebut harus direvisi lebih dulu. Untukpenelitianini hanya soal nomor 1 dengan 
pengecoh A dan D, soal nomor 4 dengan pengecoh $C$, serta soal nomor 12 dengan pengecoh A yang tidak berfungsi dengan baik karena dipilih kurang dari 5\% siswa yang mengikuti ujian.

\section{Simpulan dan Saran}

Simpulan yang diperoleh daripenelitian ini adalah:

1. Soal ujian yang digunakan dinyatakantidak valid karena tingkat validitas itemnya sebahagian besar masih tergolong rendah bahkan ada yang sangat rendah. Simpulannya soal-soal yang mempunyai kriteria yang disebutkan sebelumnya tidak dapat digunakan atau direvisi terlebih dahulu.

2. Soal ujian yang digunakan dinyatakan tidak reliabel, karena memiliki nilai dengan kategori tingkat reliabilitas yang rendah.

3. Soal ujian yang digunakansebagian besar mempunyai tingkat kesukaran sedang, artinya tingkat kesukaran soal tersebut termasuk kategori baik.

4. Soal ujian yang digunakan mempunyai daya pembeda yang termasuk kategori cukup. Hanya terdapat $12.5 \%$ atau sebanyak 2 butir soal yang tidak dapat digunakan karena memiliki tingkat daya bembeda yang tidak baik. Akibatnya soal tersebut harus diganti dengan soal yang baru.

5. Soal ujian yang digunakan mempunyai daya pengecoh yang befungsi baik.

Sedangkan, dari hasil penelitian yang diperoleh penulis dapat memberi saran sebagai berikut:

1. Dalam menyusun soal tes, hendaknya soal yang akan diujikan sebaiknya terlebih dahulu kualitas soalnya berdasarkan nilai validitas, reliabilitas, daya pembeda, tingkat kesukaran, dan fungsi pengecohnya.

2. Diharapkan kepada guru matematika untuk melakukan usaha-usaha dalam upaya meningkatkan kualitas soal matematika agar dapat mengukur hasil belajar siswa dengan baik.

3. Penelitian ini hanya terbatas pada analisis soal multiple choice, diharapkan untuk peneliti selanjutnya agar dapat menganalisis soal berbentuk essay.

\section{Referensi}

Arifin, Zaenal. 2010. Evaluasi Pembelajaran. Bandung: Remaja Rosdakarya.

Arikunto, Suharsimi. 2010. Dasar-dasar Evaluasi Pendidikan. Jakarta: Bumi Aksara.

Aunurrahman. 2010. Belajar dan Pembelajaran. Bandung: Alfabeta.

Bukhari. 2005. Teknik-teknik Dasar Evaluasi Pendidikan. Bandung: Jemmars. 
Firmansyah. 2018. Analisis Butir Soal Tes Pilihan Ganda Mata Pelajaran Pendidikan Jasmani Olahraga Dan Kesehatan Kelas VIII SMP N 1 Wonosari Tahun Ajaran 2017/2018. Yogyakarta: Universitas Negeri Yogyakarta.

Karman. 2012. Validitas dan Tingkat KesukaranSoal MatematikaSemester GanjilTahun Ajaran 2011/2012diSMPNegeri 2 Susoh. Banda Aceh: Universitas Muhammadiyah Aceh.

Masidjo. 2007. Penilaian Pencapaian Hasil Belajar Siswa di Sekolah. Yogyakarta: Kanisius.

Mursyidah. 2017. Analisis Butir Soal Ujian Matematika Kelas X SMA Negeri 9 Aceh Barat Daya Semester Genap Tahun Pelajaran 2015/2016. Blangpidie: STKIP Muhammadiyah Aceh Barat Daya. 